\title{
HMGB3 wt Allele
}

National Cancer Institute

\section{Source}

National Cancer Institute. HMGB3 wt Allele. NCI Thesaurus. Code C52078.

Human HMGB3 wild-type allele is located within Xq28 and is approximately $6 \mathrm{~kb}$ in length.

This allele, which encodes high mobility group protein B3, is involved in DNA-dependent regulation of transcription. 